African Identities,

2016, 14(4) 370-383

DOl: $10.1080 / 14725843.2016 .1154813$.

\title{
The edge of the periphery: situating the $\neq$ Khomani San of the Southern Kalahari in the political economy of Southern Africa
}

\author{
Francis, Suzanne., Francis, M. \& Akinola, A.
}

\begin{abstract}
In this article, we situate the Southern Kalahari San within the political economy of Southern Africa and within the world system. Here we draw on and critique modernization theory as a model of explanation for the lack of development found locally. In the Southern Kalahari, the $\neq$ Khomani San won a massive land claim that should have empowered and enabled local development. Yet they remain largely impoverished, while seeking out a meaningful life on the edge of the capitalist world system. Within states, contradictions remain as local diversity continues to be reproduced and modernity itself is reproduced as local diversity. The research is premised on empirical fieldwork conducted in the Southern Kalahari in 2013 and supported by a series of earlier field research over the previous five years. The San of the Southern Kalahari are not resisting modernity but drawing on aspects of it selectively for their own vision of meaningful development.
\end{abstract}

\section{Introduction}

In this article, we use the framework of the modernization-dependency discourse in order to consider the political economy of the Southern Kalahari and how it affects the $\neq$ Khomani San. They are one of the former hunter-gatherer or aboriginal populations of Southern Africa and form a small community of about 1500 individuals ${ }^{1}$ (cf. Chennels, 2002; Personal Interview, 2009) The two most common/ generic names are 'San' or the 'Bushmen'. Both are historically loaded names with derogatory overtures - 'Bushman' implying savage and 'San' meaning thief (Gordon, 1992, pp. 6-7; also see Barnard, 1992, pp. 7-11). The term Bushman may be considered derogatory but it is in common usage by the community themselves when they are not using the more specific term $\neq$ Khomani. $\neq$ Khomani is the name for the local group of related 'San' peoples who have recently come together as a community through a land restitution process. The $\neq$ Khomani San had won a massive land claim that should have formed a basis for empowerment and enabled local development. Yet they remain largely impoverished and development has been small scale and non-commercial or of 
limited commercial success or scale. Their context of living on the edge of the periphery of

the capitalist world system structures development/underdevelopment in key ways, whilst also challenging the predominance of notions of modernization.

Modernization theory, developed from liberalism may be seen to justify colonialism and imperialism; and locates the cause of African underdevelopment in internal contradictions and limitations such as cultural and traditional practices, un-democratization, and a lack of industrialization. Modernization theorists conceive of development as an evolutionary/tautological process that ends with a free market economy under a liberal democratic political system (Rostow, 1960/1990). There has been much theoretical development into modernity that ruptures the notion of an evolutionary or teleological process. Western modernity is often posed as the model to be emulated despite many examples where this fails to occur (see Comaroff \& Comaroff, 2015). In the march towards the institutionalization of democracy, traditional and cultural practices are thought to give way to more rational modes of development associated with progress. Yet, in multiple states, and indeed internationally, contemporary contradictions remain. These include the contemporary consumption of traditional and/or herbal medicine; activism around cultural self-consciousness; global forms of cultural tourism that is premised off local/traditional practices; and the adoption of indigenous rights-based charters by multiple states and the United Nations (2008). The diversity of the world has not given way to modernity and is often reproduced as local diversity (Sahlins, 1993).

Both the structuralist theories of the 1950s and dependency theory locate the causes of underdevelopment in lingering colonial trade and labour patterns (Ake, 1981; Rodney, 1958/1972). Dependency theory adopts a political economy approach to development (sociopolitical, economic and human), rejects the assumptions of the modernization arguments and locates the cause of African underdevelopment in the mode of integration of the economies of the developing world with advanced capitalist countries within a global economic system. Ake argues that if African societies adopt 'western' liberalism, they will only achieve the democracy of alienation (1981).

Other critics of the modernization perspectives claim that the modernist viewpoint is a 'regime of representation' that imposes itself on non-western societies (Everett, 1997). This facilitates not only the governance and control of these societies by the advanced capitalist world, but also imposes a hegemonic view of reality which defines non-western societies as traditional and underdeveloped (Everett, 1997). Here critiques often collapse 'western' with 'developed' and 'non-western' with 'un/underdeveloped' which echoes a particular history of colonialism coupled to European dominance. While a problematic set of terms with no actual conceptual basis, we use them here to echo these author's critique and use of terms.

Contemporary dependency theorists insist that imperialism; colonialism, neocolonialism and globalization engender underdevelopment and, further, that the 
international political economy system is exploitative and creates and maintains the core (capitalist economy), semi-periphery (developing economy) and periphery (underdeveloped economy). Dependency creates class alliances between elites at the global centre and the semi-periphery, reproducing culture, distorting social relations, and systems of livelihood and exchange under the guise of development (Ake, 1981). Here we situate the political economy of the extreme periphery - the Southern Kalahari Community - within the global political economy of the capitalist world system. 


\section{Methodology of the study}

The study is driven by field work research conducted in the Southern Kalahari in 2013 and supported by a series of earlier field research over the previous 10 years. The techniques of data gathering are semi-structured interviews and personal observations within the San community over a 10-year period ${ }^{2}$ (See Tomaselli, Dyll, \& Francis, 2008 for a full discussion about doing critical research among indigenous peoples). We adopt a constructivist approach to knowledge, locating meaning within the context in which information is collected in the Southern Kalahari. Individuals were observed and interviewed collectively and individually in their places of work or home, and over many years. The following are the categories of people interviewed: proprietor/managers of hotels and lodges, representatives of different formal and informal community structures and structures of governance, non-governmental organisations, commercial and subsistence farmers, shop owners, traditional elites, labour workers, government officials and a large number of members of the broader Southern Kalahari San community in the Molopo area. All interviewees were offered anonymity as a condition of the interviews. Where necessary, translators were drawn both from within the community (often from within the family of the interviewee) and also, to navigate the factions of the community, we drew on external translators where appropriate.

\section{Context of the study}

The question of who is indigenous has become an intriguing concept in contemporary Southern Africa (see also Watkins, 2004). The San/Bushmen are found in four countries, namely: South Africa, Namibia, Angola and Botswana. The San are the oldest inhabitants of Southern Africa where they have lived for at least 20,000 years; most of it as hunter-gatherers (Kent, 2002).

In the Southern Kalahari, the $\neq$ Khomani San (like other indigenous or first nations people) are a distinctive minority group and are caught up between cultural survival and the globalizing mission of modernization/Westernization. Some studies have shown places where the San had participated in food production, which led to international trade in the sixteenth century (Headland \& Reid, 1989). There have been contending arguments about their relationships with pastoralists, while other studies insist on evidence of alienation, exclusive life and egalitarian forager society (for a full debate see Wilmsen et al., 1990). Despite contentious debate, there is some agreement that their social structure does not seem to be tribal, in that they do not have a paramount ruler, they were not driven by accumulative or monetary considerations, their affinity with kinship patterns of descent is flexible, while consensus and communalism remain at the heart of interpersonal relations (cf. Thomas, 1989). Hence, transforming these traits into sovereign individuals as demanded by 'modernity' seems paradoxical.

The Kalahari San are not deliberately resisting 'westernization', but they see modernity through the lenses of identity recognition and cultural adherence, and this seems to invalidate the assumption of modernization theory that all societies follow a common and linear path to development. Resistance by the $\neq$ Khomani San is primarily a way to construct new identities necessary for finding alternatives to the hegemonic world view presented by the development discourse. This 
resistance has been interpreted by Everett as a ploy to protecting land and houses from expropriation, and about demanding a fair share of development 
benefits in the form of education and services (1997). Everett's position is not without merit, however, personal observations and interviews reveal that the struggle for identity and cultural sustainability is their strongest motivation for resisting drastic change.

Modernization theory also posits that once the comforts of custom and ancient patterns of thought and deeds are rejected, progress would follow its natural course. A shift from the extreme spectrum of Bushmen in relation to hunting and gathering to the moderate Modern man, characterized by small-scale commercial livestock farming, is a move towards modernity and thus a move towards further integration into the world economic system. However, despite their shift away from hunting-gathering, they are not seeking to replicate modernity even as it structures their lives in key ways. Just as modernity and the capitalist world system nonetheless shaped their lives during the rise of industrial capital in the late nineteenth century.

\section{The \#Khomani San and industrial capital in the region of Southern Africa}

The discovery of minerals in the late nineteenth century - diamonds in Kimberley and gold on the Rand - abruptly changed the political economy of the region of Southern Africa. As industrial capitalism replaced the merchant capitalism of the earlier centuries, colonial powers, industrial capital and labour recruiting agencies worked hand in hand to secure a cheap supply of labour for the emerging mines and plantations of the industrial economy. The imposition of hut taxes (to be paid in cash) was a further contributory factor in the political control of the region for the benefit of industrial capital. The creation of the migrant labour system fractured the peasantry, as they became straddled across two economies of the region; the urban industrial cash economy and the rural subsistence livelihoods of earlier centuries (see First, 1982; Hyden, 1980). Land alienation, labour controls and migrancy became a feature of life for most Africans across Southern Africa (Van Onselen, 1980). This culminated in the 1913 Land Act that restricted the majority of the South African population to $13 \%$ of the land. The Natives Land Act [Act No.27 of 1913] which regulated the acquisition of land by 'natives' was the first substantial piece of segregationist legislation passed by the Union Parliament.

Although the San were not excluded from the colonial onslaught on the African continent, the Southern Kalahari San largely remained outside of the migrant labour system. However, the scramble for Africa and the creation of the migrant labour system with the fixing of borders cut across the area occupied by the Southern Kalahari San. In South Africa, in the area immediately south of the Botswana border and east of Namibia (now the Kgalagadi Transfrontier Park and area around the Molopo and Kuruman Rivers), the land was only surveyed between 1913 and 1917. The land survey opened the land up for settler societies practising farming (see, e.g. Legassick, 1998/1999). However, few moved to this region due to a hostile and arid environment. The movement and activities of other groups of peoples such as the Korana and the small and dispersed settler population had little immediate impact in integrating the San into settler agriculture until 1931 with the creation of the Gemsbok National Park (now Kgalagadi Transfrontier Park). As settler farmers were moved south out of the area of the park to new farms along the Molopo river, the Southern Kalahari San were subjected to new and fixed borders of private ownership and a drastic 
reduction in land usage. This then exposed them fully to the agricultural labourtenant system - a feature of the migrant labour system - and any independent hunter-gatherer existence (in 
this region) largely came to an end. This is reflected in the Afrikaans names of all of our San interviewees and their parents and grandparents.

The new role of San as farm labourers greatly impacted their social identity and culture. Past practices of hunting-gathering became marginal activities that coexisted with farming and served to augment meagre salaries with extra food and medicines. Few eked out an existence along the border of the park moving between working in the game reserve or as farm labourers and hunting as they were able to (Crawhall, 2001). Many San were dispersed throughout the Northern Cape, and as far south as beyond the Orange River (Personal Interview, 2013). It was in the early 1970s that the last remnants of the San living in the park were removed from it where they settled at the town of Welkom $10 \mathrm{~km}$ from the gate. This community formed the original basis for the land claim.

\section{The $\neq$ Khomani San land claim in the post-apartheid period}

The $\neq$ Khomani San have faced multiple ejections from their original location, but in the post-apartheid period were able to claim restitution of land under the Restitution of Land Rights Act. The Restitution of Land Rights Act [Act 22 of 1994] was part of South Africa's post-apartheid broader land policy framework which included two other pivotal land programmes. These were the redistribution of land programme, made possible by Section 22 of the Constitution and the Land (Labour Tenants) Act of 1994. The Restitution of Land Act was concerned with the restoration of land title to individuals and communities that had been previously dispossessed due to racially prescribed legislation since 1913. The San's restitution claim was comprised of 36,000 ha of farm land and a small tract of the Kgalagadi Game Reserve, in the Northern Cape, South Africa. The land claim emerged from a clear historic displacement of a small set of families (Crawhall, 2001) that was enlarged as a result of discoveries of lineage to the supposedly extinct $\neq$ Khomani San. The notion of a cohesive ethnic group was further augmented by linking extant families to those that could speak the original $\mathrm{N} / \mathrm{u}$ language, ${ }^{3}$ which serves as leverage and a unifying factor in 'influencing' the government of South Africa to yield to the quest for access to farmland and relocation under the distributive land act of 1994. This is in consonance with Sylvain's position that people are drawing upon the idea of culture as an instrument for securing sociopolitical, economic and development resources (Sylvain, 2005).

\section{The ¥Khomani San: error of misconception?}

Although the Bushmen have been portrayed as a close-knit communal and egalitarian community, personal interviews and observations reveal clashes in interests between different sectors of the community. There are still some levels of communalism, but evident divisions, factionalism and rancour exist. The claim that the community is highly united was sharply refuted by a cross-section of the community. One of the respondents blurted out, 'We are not united and this has chased away donor organizations. It is fight every time ... one of the donor organizations that left here in anger said, your House is not in order' (Personal Interview, May 2013). There are recorded high rates of crime and thefts: this was particularly shocking. One of the farmers recalled that about one hundred of her 
livestock was stolen within a year, while people from the community kept vandalizing water pipes and other public amenities 
(Personal Interview, May 2013). The local police chief echoed concerns about crime and vio-

lence among the community, much of it linked to drinking (Personal Interview, May 2013).

Contrary to their mode of age-long livelihood and lifestyle, the San has actually imbibed some traits of democratic governance that manifests in the creation of divergent unstable political structures, engaging in political participation and economic activities, which strengthens the debate between the 'traditional' and 'modern' Bushmen. But contrary to existing literature that sharply divides the community along this traditional-modern dichotomy (cf. Robins, 2001), no claim of such exists within the Bushmen community any longer (Personal Interview and Observation, May 2013). The categorization has faded away by the tides of ages and exposure to modernity (Personal Observation, May 2013). Interestingly, few of the $\neq$ Khomani San also saw themselves along this divide, while the majority could not locate the basis for the classification (Personal Interview and Observation, May 2013). However, it was discovered that the Bushmen - as a community engage in both traditional and modern lifestyles, though the degree varies. This fact is also re-emphasized by Solway that they all retain most of their ancient practices, effect just a slight compromise to modern living and engage in some rudimentary process of agricultural farming that is accepted within the San (Solway, 1998).

Another point supporting the dismissal of the traditional-modern Bushmen fallacy is the contradiction between one of the symbols of the tradition's (craft-sellers) appearance and profession. The craft-sellers do not wear clothes, except a skin-like short pant to cover their private parts in tune with a perceived or stereotyped ancestral dressing code, yet they have been engaging in commercial activities (selling crafts and collecting money from tourists that want to take their photograph) for a long period of time (some since the 1970s) (Personal Interview, May 2013). The craft-sellers unanimously oppose any attempt to expand or 'modernise' their business, but still wish for improved housing conditions by the government. Previous attempts to develop local craftmaking were attempted through the Sisen Craft centre a number of years ago. The project failed once the funding ended and saw no lasting impact on craft production or sales. Ironically, the current craft-sellers also engage very modernistic discourses/stereotypes of what a real 'bushman' should look like to sell their authenticity to lure tourists (see also Tomaselli \& Wang, 2001), In discussions about their various occupations, one of the craft-sellers declared that 'I love my job', while a farmer said, 'Farming is my life ... once I get housing, water and electricity in the farm, I am fine' (Personal Interview, May 2013). A striking lifestyle of the $\neq$ Khomani San is this strong feeling of self-satisfaction, contentment and reluctance of the Bushmen to engage fully into intensive capital-driven and profit-maximizing capitalism. Their reported satisfaction comes from engaging in economic activity they find reaffirms their identity and lifestyle choices, rather than what is best economically. Others within the community refuse to sell crafts as they refuse to dress up as a 'bushman'. This was also a form of political engagement - to draw upon stereotypes that enable international support and advocacy on their behalf (Francis \& Francis, 2010).

It is also intriguing to discover that small-scale commercial farming within the $\neq$ Khomani San existed prior to the land claim and even before democratic governance in 1994. A commercial farmer corroborated this fact by revealing that 
the family has been involved with commercial livestock farming over 30 years ago (Personal Interview, May 2013). What is more captivating was that the commercial farmer staunchly declines shifting towards a more broad-based commercial farming: sales of livestock remains a means of survival and 
not for capitalist accumulation to recreate wealth. This suggests that the gradual integration of the community to small-scale market capitalism commenced before the land claim, but remains a peripheral activity. The San had worked for multiple generations on local farms as labourers, but do also seem to have engaged in independent farming of their own, albeit not on their own land.

\section{The Southern Kalahari and the unsung transformation agenda}

The quest of the Kalahari San population for development is not driven by economic interest, but sheer preservation and recognition of age-long identity, value system and extreme nationalism. There is unanimous response across the community that their priority is just to take care of their family and for their children to have a more prosperous life than they did. An extensive engagement with the community and observation found high degree of prospects and opportunities for self-sustainment and development within the limit of their traditional lifestyles, ironically, these opportunities remained untapped. It was also discovered that the Bushmen are not capacitated to expand the frontiers of their cultural resources for economic gains, on the one hand, and overall development of the South African economy and regional development, on the other hand.

The Southern Kalahari community are renowned for indigenous knowledge in medicinal plants and traditional healing (Wynberg, Schroeder, \& Chennells, 2009); some of these locally produced drugs are used as slimming and energy-enhanced drugs worldwide. Also, indigenous knowledge systems has become the new lens through which African states may engage differently - and on their own terms with many other parts of the world. This applies equally to indigenous (medicinal) knowledge drawn from cultural, historical and social background. There is an ongoing Traditional Medicine Plants project, while there is a traditional healer who acts like a native doctor. The $\neq$ Khomani San have been found to use 59 wild plant species on a regular basis, mainly for medicine (Mannetti, 2011). The wild plant use may echo more an issue of cultural continuity than revival, but it does point out the important role of tradition and the continued transmission of traditional knowledge within the community despite the forces arrayed against them (cf. Comaroff \& Comaroff, 2009; Sahlins, 1993).

The new 'waves' toward issues of cultural revival, global tourism and indigenous knowledge-creation has swung to the advantage of the $\neq$ Khomani San. Despite the irresistible spread of global networks of culture and influence, $\neq$ Khomani remained averse to any attempt to further distort their sociocultural, traditional, language and spiritual identity. The desire of the community to establish a modern hospital is undeniable. There is no hospital or clinic within the immediate community. The nearest health clinic is in Askham (13 km away), while the closest hospital is in Upington (190 km away). Despite a clear desire for better medical facilities, they also want the right to choose between traditional and modern medicine. The traditional healer highlighted different traditional skills and medicine abundant in the community, but cites lack of funding and facilities as a major health challenge. According to him,

There is always a problem. I have to go so far looking for required plants and could not plant here because of lack of funds. There is a plant project in process but no money to expand it. For example, I have an energy enhancing plant which is very effective, but could not expand it. You cannot cure people without money, plants cost 
money. Also, why can't I get a traditional hospital where patients will come like the modern hospital? (Personal Interview, May 2013) 
He claimed that aside from the use of medicines (both traditional and modern), there are other healing skills such as massage, touch and realignment to redress heart conditions or other ailments that the San can offer. Within the community, there is broader support for a healing centre to be built on Erin farm, but the traditional healer was at the time of the interviews unable to commit to such a programme. He is, however, involved in a partnership arrangement with the University of South Africa (UNISA) to utilize the wealth of experience deposited in the traditional healer to train students and teachers in indigenous knowledge on traditional healing and local medicine plants. ${ }^{4}$ These students were drawn from the nine provinces across South Africa.

A respondent who has been engaged in a different collaborative project revealed an initiative titled 'Enlargement by Transformation' by the Northern Cape Provincial government to offer similar training under the Indigenous Knowledge System of South Africa (IKSA). Despite these projects, health and healing remain a vital concern for the community and the local traditional healer in particular. He reported that in early 2013, there were two cases of avoidable deaths as a result of ill health, which was due to the lack of an accessible modern hospital and what he saw as undeveloped traditional alternatives. Here again there is a desire for a traditional option alongside a modern one as opposed to a desire for one or the other. Therefore, tradition is not opposed to modern but part of a set of possible alternatives that comprise syncretic affiliations and meanings.

Within such syncretic alternates of the $\neq$ Khomani San is the use of cultural events that they have linked to commercial festivals, namely the 'Heritage Festival', the 'Kalahari Desert Festival' and the spiritual 'trance dance'. The trance dance is said to link the community with their ancestral gods and the spirit world. During a traditional trance dance, people converged $\backslash$ around a fire and dance around it until it become intense and some of them taken over by 'spirits'. These trances are said to heal the sick through the spiritual manifestation. These are performed for a fee publicly for tourism and are claimed by members of the community to be held privately for healing. A number of dances over the years have been observed but they never induced any deep trance states. Most of these had been spontaneous events with a few individuals around a fire as well as, on one occasion, a more elaborate set-up for a fee. Sadly and ironically, the diseases often in need of treatment were introduced through modernity such as AIDS or tuberculosis and general ill health due to alcoholism and drug abuse. ${ }^{5}$

The Bushmen community were constructing a 'Healing Centre', to host spiritual and healing dances as well as serving as another tourist attraction. These developments are attempts to articulate with the national and global economy despite their local content and local meanings. Similarly, there is also a 'Heritage Festival' that was held in September 2012. This was hoped to be sustained to offer people within the community and across South Africa the opportunity of learning about the cultural heritage of the Kalahari community instead of partaking in the political rallies that recently characterized the public holiday in other parts of South Africa. It appears to be supplanted by The Kalahari Desert Festival. ${ }^{6}$

SASI facilitated the hosting of the First 'Kalahari Desert Festival' (KDF) in March 2013, which was promoted by Northern Cape provincial government under tourism promotion activities to celebrate the indigenous cultures of the Kalahari community, that of South Africa, and Southern Africa region. The exhilarating event was organized by SASI in collaboration with the $\neq$ Khomani San, 
Department of Economic Development and Tourism, and Department of Sports, Arts and Culture, Northern Cape Province. The highly successful and enthralling

celebration of diverse cultures was held in the 'Bushman camp'. This was originally developed by SASI to 'connect people back to their ancestral "Bushman" origin' (Personal Interview, May 2013). This attracted many cultural troupes, not only from the Southern Kalahari but across South Africa and the Southern African region. SASI promised to make subsequent festival a worldwide ceremony. These ideologically based events do articulate with the global political economy and indeed are local attempts to do so.

The post-cold war era has witnessed a proliferation of ideologically based armed insurrection against the state as a response to resource conflicts (Akinola, 2011). Mineral resources, especially in developing countries, have attracted both world capitalist powers and multinational corporations. These have acted as agents of development in these zones, thereby integrating these resource-rich societies into global capitalism. The Multinational Corporations, however fuel conflict in these regions. The absence of mineral resources in the Southern Kalahari has to some degree disconnected the 'world' historically' from the economic plights of the Bushmen as well as ensuring their marginalization to the extreme periphery.

The common global discourse of the $\neq$ Khomani San is around the rights of indigenous people, identity rights and the global search for the 'First Citizen'. However, the Bushmen have been allocated about 36,000 ha of land, which in itself represents a resource of high magnitude, ${ }^{8}$ especially in a country where the mass of the population are allegedly deprived of landownership. This study does not intend to shy away from perspectives against the allocation of 'such huge land for people that does not necessarily need it ... the land is just wasting away' (Personal Interview, May 2013), but when the capacity of the society is well harnessed and opportunities unravelled, then the availability of such magnitude of land would be an advantage, especially in establishing industries, amusement parks, lodges, markets, rail station and even a local airport. This would easily integrate the community in global markets, which would trigger the harnessing of their resources and indigenous innovations by the world. This would also create easy access to the Kalahari Park and other tourist attractions in the immediate environment.

The availability of land has increased the prospects of large-scale and broadbased commercial livestock farming. Presently, most of the commercial farmers do not have the immediate vision of connecting to a market-driven capitalist world, but the gradual opening up of the landscape for entrepreneur activities might change their perceptions. This possibility is located in the spill-over discourse. One of the interviewees is only awaiting his pension and funding from the bank to fully establish a large commercial livestock farm. Moreover, he desires the opportunity to be a middle man, engaging in the 'buying and selling' of sheep and goats. This could possibly increase competition among the farmers, which will result in an expanded livestock markets. In such conditions, attracting a 'hide and skin' industry would be realistic, while industrialization could then be expected.

\section{Globalization of the Southern Kalahari: implications for sustainable development}


Within the framework of a democratic state like South Africa, every attempt by the state to initiate any developmental processes in a particular region is conceived as a pre-condition for integrating the semi-periphery to the periphery. The gradual integration of the San community into provincial and national developmental projects represents the first step of globalizing the San community. Here, we refer to the integration into the global capitalist economy 
and not the globalized political discourses that they are immersed within via academics, activists and other indigenous peoples. The logic of capitalism is the gradual movement of the 'privileged' of the 'disadvantaged' to join the urban centre due to opportunities of better education and more rewarding productive labour engagements. Many of the San children are found in high school, mostly in a boarding facility, while few have moved further to the nerve-centre of South Africa to the cities of Upington and even fewer further afield to Cape Town. While education remains a viable way to empower the community, it does mark a potential movement out of the periphery and therefore out of the community.

The process of electioneering in the community, commercialization of culture, continued commercial farming with the possibility of expansion, the influx of tourists from across the world and gradual expansion of the traditional medicinal plants industry remains a softening-up process for the integration of the San economy to the international economic order. A survey of several lodges along the Molopo metropolis, and immediate surrounding reveals the increased influx of outsiders into the Southern Kalahari for all kinds of reasons. Many of the lodges have recorded tourists, doctoral students, researchers and hunters spending days, and some weeks in the San community (Personal Interview and Observation, May 2013).

Visitors come from all over South Africa and from as far afield as Belgium, Italy, France and Germany. Many of the lodges and business ventures were owned by non-San people, who have an age-long relationship with the San and see themselves as part of the community (Personal Interview and Observation, May 2013). The lodges in the vicinity of the land claim (including Molopo Lodge which is surrounded by it) on which the $\neq$ Khomani San reside serve as a stopover point to people visiting the Kgalagadi Transfrontier Park, Namibia or Botswana, are beneficial to the community and to the cause of globalization.

The visitors, tourists and researchers depend on the Bushmen as tourist guide, trackers and interpreters, while some researchers are partnering with the community in a loose arrangement as part of their academic community engagement. A particular researcher from a renowned University in South Africa decided to engage a multinational company to extend its social responsibility to the community, while another tried to link the community to an NGO towards establishing a radio station (Personal Interview, May 2018).

The initiatives to expand the audience and cultural groups from all over the world to the subsequent 'Kalahari Desert Festival' is like a double-edged sword that further exposes the Bushman into international discourse, popularizes their culture and provides the opportunity to showcase their tourist potentials. The craft-sellers might be given a chance to showcase their craft skills, and turn it into economic opportunities. The trance dance ${ }^{9}$ provides another avenue to attract influx of foreigners into the community. It could also fascinate researchers and students working on alternative to medical healing process either modern or traditional plants, while the sick from all kinds of places could exploit such alternatives, especially in the contemporary world of incurable illnesses. ${ }^{10}$

The gradual removal of states borders by the forces of globalization and, more importantly, the integration of the Southern African Development Community (SADC) member states could serve the economic interests of the San. One of the intents of the establishment of SADC - formerly Southern African Development Coordination Conference (SADCC) - was to expose the Southern African region to the global market in order to 'prevent the region from becoming further alienated and 
marginalized within the world economy (see Lee, 2000) The Southern Kalahari could soon turn into a border town where people from the three sides (Botswana, Namibia and South Africa) could facilitate unrestricted business transactions. This could engender the 
advancement and integration of transportation and communication network among the three countries. One of the basic challenge for tourists and other visitors has been transportation constraints. Though there are a few airstrips in the Kgalagadi Transfrontier Park, the establishment of an airport and linkages with rail transportation would trigger sustainable development in the community, which would also dramatically expand trade and business among these countries. The more integrated multi-cultural societies are, the better for global capitalism.

\section{Conclusion}

This article has explained the various social processes through which the $\neq$ Khomani San have tried to coexist within expanding capitalism, engaged in sociocultural dynamics that triggered such attitudes, and highlighted the socioeconomic processes that engendered exploitative labour relation and impoverished the San. The study further examined how the advent of agriculture and global capitalism, through colonialism, generated alienation and impacted on the rudimentary economy of hunting and the cultural affinity of the $\neq$ Khomani San, which has survived tens of thousands of years. No doubt, the Kalahari community is characterized by poverty, discrimination and social rejection, the decline of sociocultural identity and acculturation, battles for economic survival and livelihoods, human right violations both as individuals and a group, and mass impoverishment. ${ }^{11}$ It is instructive not to regard the cultural adherence and resistance of modernity of the Southern Kalahari as acceptance of poverty and impoverishment: they desire change and development, but do not want their culture swept away by the tide of globalization, at least not at present.

Divergent perceptions of the Southern Kalahari dialogue and who is really the 'Bushmen' have distorted the reality of the cultural identity, survival strategies and political economy of the $\neq$ Khomani San. The San value system presents a unique and complex political economy in a globalized environment driven by market capitalism and economic motivations. Within this, we claim that indigenous knowledge and the preservation of identity and culture is in no way inimical to national or regional development, nor is it significantly antithetical to capital expansion. Ethnicity and culture is increasingly becoming commodified globally (see Comaroff \& Comaroff, 2009). We claim that the San community will soon be integrated with the international system either through economic or cultural network of relations.

The apparent lack of mineral resources further 'alienates' the community from the mainstream of international political economy, and this confirms the San as the periphery of the semi-periphery within the Southern African political economy. However, the shift from peasant farming into some level of commercial livestock farming, ongoing establishment of expansive traditional medicinal farms, massive land resources, the launch of expansive cultural festival, the gradual influx of tourists to the Southern Kalahari and the historically symbolic Kimberleycapitalist connection could soon launch the San landscape into global capitalism. This will have great implications for both the South African and the regional political economy.

The South African Government is not likely to be too eager to respond to the plight of the San community, aside the slim possibility of the recognition of the $N / u$ original language as a recognized national language, it beholds on entrepreneurs, 
NGOs and international donors to rise to the challenges of the unique community. Whether that arises internally or comes from outside is not yet known. What is known is that whatever challenges are faced by this indigenous community will not transform their conception of their world, neither will it blur their understanding about the world around them. 


\section{Notes}

1. Many of the Khomani San live away from the area but the $\neq$ Khomani website found at http://www.khomani.co.za/ also cites approximately 1500 individuals. See also Chennels, (2002).

2.Dr Michael Francis has been doing research in this community, first as a graduate student since 2003 and then as a university scholar, Dr Suzanne Francis since 2009 and $\mathrm{Dr}$ Akinola became acquainted with this research site while a PhD. student during 2013.

3. The N/U language is seen as the original language of the local San population and at the time of the land claim was only spoken by 12 people.

4. The document of partnership was shown to us during personal interviews in May 2013.

5. We document this elsewhere in an unpublished article.

6.http://www.kalaharidesertfestival.org/

7.The absence of large scale mineral deposits in the area within the Southern Kalahari is what kept international industrial capital at bay. We refer here not to a lack of economic opportunities on a small-scale level, but the kind of opportunities that brought industrial capital into the region in the late nineteenth century and colonial conquest to replace the forms of trade that had occurred earlier across the region of Southern Africa.

8.This is not in any way to suggest that the land is agriculturally productive, although there is sustainable sheep farming on Scotty's Fort (some supported by other local farmers), cattle farming, a medicinal plant project and a game farm is in production on Erin farm.

9.This is a healing dance common to San communities across the Kalahari that also appears in literature such as Guenther, (1992).

10.For a discussion on the healing potential of the Kalahari as well as a discussion on this community as a marginalised minority within South Africa (see Isaacson, 2004).

11. See http://www.krugerpark.co.za/africa_bushmen.html

\section{Disclosure statement}

No potential conflict of interest was reported.

\section{Funding}

The fieldwork for this article was funded by a Strategic Research Grant awarded to Professor Suzanne Francis from the College of Humanities, University of KwaZulu-Natal.

\section{Notes on contributors}

Suzanne Francis is an associate professor in Political Science at the University of KwaZuluNatal, South Africa. She researches and publishes on San history and politics, politics in KwaZulu-Natal, political elites, value systems and institutions, democracy and research methodology in African conflict and post-conflict states.

Michael Francis lectures Economic History and Development Studies at the University of KwaZuluNatal. He researches and publishes on indigenous peoples and development, socio-economic change across Africa, and performs applied research for development and resettlement.

Adeoye Akinola is a political scientist who researches and writes on African politics and specialises in African political economy and radical political economy. At the time of writing, he was a PhD scholar at the University of KwaZulu-Natal, South Africa. 
Ake, C. (1981). The political economy of Africa. London: Longman.

Akinola, A. O. (2011). Niger Delta crisis: The nexus between militants' insurgency and security in West Africa. African Security,4, 65-80. 
Barnard, A. (1992). Hunters and herders of Southern Africa: A comparative ethnography of the Khoisan peoples. Cambridge: Cambridge University Press.

Chennels, R. (2002). The ¥Khomani San Land Claim. Cultural Survival. Retrieved January 27, 2016, from

https://www.culturalsurvival.org/ourpublications/csq/article/the-khomani-san-landclaim Comaroff, J. L., \& Comaroff, J. (2009). Ethnicity Inc. Chicago: University of Chicago Press.

Comaroff, J., \& Comaroff, J. L. (2015). Theory from the South: Or how Euro-America is evolving toward

Africa. Oxford: Routledge.

Crawhall, N. T. (2001). Written in the sand: Auditing and managing cultural resources with displaced

indigenous peoples: A South African case study. Cape Town: South African San Institute.

Everett, M. (1997). The ghost in the machine: Agency in "Poststructural" critiques of development.

Anthropological Quarterly, 70, 137-157.

First, R. (1982). Black gold: The Mozambican miner, peasant and proletarian. Brighton: Harvester

Press. Francis, M., \& Francis, 's. (2010). Representation and misrepresentation: San regional advocacy and the global imagery. Critical Arts, 24, 40-57.

Gordon, R. (1992). The Bushman myth; the making of a Namibian underclass. Boulder: Westview Press. Guenther, M. G. (1992) 'Not a Bushman Thing.' Witchcraft among the bushmen and hunter-gatherers'. Anthropos, Bd. 87: 83-107.

Headland, T. N., \& Reid, L. A. (1989). Hunter-gatherers and their neighbors from prehistory to the present. Current Anthropology, 30, 43-66.

Hyden, G. (1980). The resilience of the peasant mode of production. The case of Tanzania. In R. M. Bates \& M. F. Lofchie (Eds.), Agricultural development in Africa. Issues of Public Policy. pp. 275-300, New York: Praeger.

Isaacson, R. 2004. The healing land: The Bushmen and the Kalahari Desert. New York: Grove Press.

Kent, S. (Ed.). (2002). Ethnicity, hunter-gatherers, and the "Other": Association or assimilation in Africa. Washington, DC: Smithsonian Institution Press.

Lee, M. C. (2000). Development, co-operation and integration in the SADC region. In W. Dani (Ed.), Nabudere (2000) globalization and the post-colonial African state (pp. 121-137). Harare: African Association of Political Science (AAPS).

Legassick, M. (1998/1999). The racial division of Gordonia, 1921-1930. Kronos: Journal of Cape History, 25, 152-186.

Mannetti, L. (2011). Understanding plant resource use by the $\neq$ Khomani Bushmen of the Southern Kalahari (Unpublished master of science dissertation). University of Stellenbosch.

Republic of South Africa. The Natives Land Act [Act No.27 of 1913].

Republic of South Africa. The Restitution of Land Rights Act [Act 22 of 1994].

Robins, S. (2001). NGOs, 'Bushmen' and double vision: The p Khomani San land claim and the cultural politics of 'Community' and 'Development' in the Kalahari. Journal of Southern African Studies, 27, 833-853.

Rodney, W. (1958/1972). How Europe underdeveloped Africa. Washington, DC: Howard University Press. Rostow, W. W. (1960/1990). The stages of economic growth: A noncommunist manifesto (3rd ed.). Cambridge: Cambridge University Press.

Sahlins, M. (1993). Goodbye to tristes tropes: Ethnography in the context of modern world history. The Journal of Modern History, 65(1), 1-25.

Solway, S. J. (1998). Taking stock in the Kalahari: Accumulation and resistance on the Southern African periphery. Journal of African Studies, 24, 425-441.

Sylvain, R. (2005). Disorderly development: Globalization and the Idea of "Culture" in the Kalahari. American Ethnologist, 32, 354-370.

Thomas, E. M., (1989). The harmless people. New York: Vintage Books.

Tomaselli, K. G., \& Wang, C. (2001). Selling myths, not culture: Authenticity and cultural tourism. Tourism Forum South Africa, 1, 23-33.

Tomaselli, K. G., Dyll, L., \& Francis, M. (2008). "Self" and "Other": Auto-Reflexive and indigenous ethnography. In N. K. Denzin, Y. S. Lincoln, L. T. Smith (Eds.), Handbook of critical and indigenous methodologies (pp. 347-372). London: Sage.

United Nations. (2008). United Nations declaration on the rights of indigenous peoples. Retrieved August 5, 2014, from http://www.un.org/esa/socdev/unpfii/documents/DRIPS_en.pdf 
Van Onselen, C. (1980). "Labour mobilisation in a Colonial Political Economy", Chibaro: African mine labour in Southern Rhodesia 1900-1933. Johannesburg: Ravan Press.

Watkins, J. (2004). Indigenous archaeology: American Indian values and scientific practice. Walnut Creek, CA: AltaMira.

Wilmsen, E. N., Denbow, J. R., Bicchieri, M. G., Binford, L. R., Gordon, R., Guenther, M., \& Lee, R. B. (1990). Paradigmatic history of San-Speaking peoples and current attempts at revision [and comments and replies]. Current Anthropology, 31, 489-524.

Wynberg, R., Schroeder, D., \& Chennells, R. (2009). Indigenous peoples, consent and benefit sharing: Lessons from the San- 